\title{
Healtheare Expenditure on Childbirth in India: Two Part Model Analysis
}

\author{
Mandeep Kaur ${ }^{1}$ and Sumit Kumar ${ }^{2, *}$ \\ ${ }^{1}$ Guru Gobind Singh College for Women, Chandigarh-160019, India \\ ${ }^{2}$ Sri Guru Granth Sahib World University, Fatehgarh Sahib-140407, India
}

*E-mail: sumitkumar2382@gmail.com

\section{ARTICLE INFORMATION}

Received: June 15, 2018

Revised: August 31, 2018

Accepted: September 15, 2018

Published online: October 08, 2018

Keywords:

Two-part models, Childbirth, Health expenditure, institutional deliveries, inpatients

DOI: https://doi.org/10.15415/jmrh.2018.51001

\begin{abstract}
The aim of the study is to estimate the extent and determinants of healthcare expenditure of inpatients on childbirth in India. The study is based on sample of 14510 women who gave birth to a child (whether live or still-birth, vaginal or caesarean). To estimate the determinants two-part models has been utilised. The results indicate that women spent on average around INR 9103 per childbirth in hospitals. There are also wide variations in the spending pattern of women on childbirth. Household size, economic status, occupation, religion, and caste impact the expenditure on childbirth in hospitals. There are also wide-variations in the spending of women belonging to different geo-graphical locations of India. Surgeries/caesarean or utilisation of facilities like special room and diagnostic tests etc. also significantly increase the expenditure. Women opting for public health facilities or having insurance spend less as compared to others. Government of India should increase investment in health to strengthen its current infrastructure. There is dire need to improve the quality of public health facilities, to reduce the regional imbalances in health facilities, to improve the coverage of health insurance in India for equitable and pro-people health facilities.
\end{abstract}

\section{Introduction}

Government of India through its recent health initiatives like National Rural Health Mission (NRHM), Janani Suraksha Yojana (JSY, translation: Mother protection plan), Janani Shishu Suraksha Karyakram (JSSK, Translation: Motherchildren protection program) has enhanced the utilization of public health services and this lead to decline in maternal, infant and neonatal mortality(IIPS \& ICF, 2017), (CBHI, 2016). These initiatives coupled with rising per capita income of Indians may have increased the accessibility and affordability of health services for childbirth. The increases in literary rate may also have increased the acceptability of health services for pre-natal, natal, and post-natal health services. Probably due to these factors, the institutional deliveries in India have increased from 38.7 percent in 2005-6 to 78.9 percent in 2015-16. Infant mortality rate (per 1000 live births) has declined from 57 in 2005-06 to 41 in 2015-16. Under five mortalities (per 1000 live births) has also declined from 74 to 50 in the same time period(IIPS \& ICF, 2017). Maternal mortality rate (per 100000 live births) has declined from 254 in 2004-06 to 167 in 2011-13(NITIAyog, 2017). Despite of all these improvements in the recent past, India failed to achieve the millennium development goals to reduce the infant mortality rate to '28' and maternal mortality rate to ' 109 ' by 2015 . There are also wide-spread disparities in IMR and MMR among the states of India. Few states of India like Kerala, Maharashtra, Tamil Nadu perform far better than other states like Uttar-Pradesh and Bihar. Not only in health outcomes but there are wide inequalities in health services infrastructure and human resources in health sector (CBHI, 2016). Moreover, health expenditure in India is predominately financed by households themselves. These out of pocket expenditure in general and expenditure on childbirth in particular can cause financial distress especially in case of poor households(Tripathy, Shewade, Mishra, Kumar, \& Harries, 2017). The safety nets like insurance are playing their part but the coverage of insurance in India is very low as around 216 million people were covered under any health insurance scheme (both public and private) out of 1223 million population in 2013-14 (CBHI, 2016). The task of accessible, affordable, and acceptable health services for childbirth for all the segments of society requires more determination and fortitudes of central and states government of India. In this situation, understanding the factors impacting the expenditure on childbirth becomes necessary. The factors impacting favourably or unfavourably the expenditure on childbirth can assist in designing 
equitable policies. Furthermore, the factors impacting the expenditure of childbirth may undergo several changes from time to time. Therefore, health expenditureand the factors impacting it, could be studied from time to time. The present study is dedicated to this cause. More specifically, the objectives of present study are i) to estimate the expenditure ofinpatients on theinstitutional deliveries and ii) to identify the determinants of health expenditures of inpatients due to childbirth.

\section{Data and Methodology}

National sample survey organisation (NSSO), established by Ministry of Statistics, Government of India, regularly collects data from households, individuals, and/or firms on consumption, employment, demographics, education, and health. NSSO in its $71^{\text {st }}$ Round collected data on social consumption on health and education of Indian population. This survey was carried out from January to June 2014. A multistage stratified random sampling approach was utilised by NSSO to select the representative sample form India and 4577 villages and 3720 urban centres were surveyed. In these rural and urban centres, 65932 households were interviewed by selecting 36480 households from rural areas and 29452 households from urban areas and detailed information (including socio-economic and morbidity profile) from 333104 individuals were collected. For the present study, information on women giving childbirth as in-patient of a medical institution during the last 365 days from date of survey was utilized. The study sample comprised of 14587 women from all over India. For 77 women, information on some indicators were missing due to death of the patient or any other reason. Therefore, active sample for the present study consists of 14510 women who gave birth to a child (whether live or stillbirth, vaginal or caesarean) within last 365 days from the date of survey. Detailed information on type of medical facility, direct medical expenditureslike doctors' fees, expenditure on medicines, diagnostic tests, physiotherapy etc., direct non-medical expenditures like transports fees, lodging charges etc. was collected. Information on indirect expenditures like income losses and costs of accompanying persons was not collected in the survey, therefore the present analysis is based upon direct costs of healthcare. Since the survey was multistage random sample survey, sample weights given by the NSSO has been applied in the present study. To identify the factors of expenditure by inpatients on childbirth, variety of regression models has been proposed in the recent years (Jones, 2010)(Gregori, Petrinco, Desideri, Merletti, \& Pagano, 2011). For large samples it has been noted that simple regression model estimated by Ordinary Least Square (OLS) performs
satisfactorily(Jones, 2010). However, in the present situation for study sample of 14510 women, around 12 percent of the women incurred no medical expenditure on hospitalisation due to various schemes and policies of Government of India to promote institutional and safe childbirth. Thus, in the present situationHeckman sample selection and two-part models are the choice to identity the determinants of expenditure. There has been debate over the superiority of these methods and two-part models are slightly preferred over the Hackman sample selection (Maruotti, 2010; Dow \& Norton, 2003; Farewell, Long, Tom, Yiu, \& Su, 2017; Jones, 2010; Leung \& Yu, 1996; Madden, 2006; Neelon \& O’Malley, 2019) since they resemble accurately a principal-agent type model, where homogeneous, observable, counted outcomes are subject to a prior, exogenous. Therefore, for present study, two-part model has been utilised. In the first part, factors responsible for the expenditure on childbirth and in the second part, factors responsible for quantity of expenditure conditional on expenditure on childbirth has been explored.

The first stage defines a dichotomous variable $\mathrm{D}$ indicating the regime into which observations of the dependent variable $\mathrm{Y}$ falls:

$$
D=1 \text { if } Y=X_{1}^{\prime} \beta+\varepsilon_{1}>0 \text { and }
$$

$D=0$ if $Y=0$

$Y$ is total medical expenditure done by household on inpatients due to childbirth. Vector $X_{1}$ includes its determinants, $\beta$ is a vector of associated parameters, and $\varepsilon_{1}$ is an error term assumed to have a standard normal distribution. After estimating $\beta$ using Logitor Probit estimation methods, the second stage involves aregression of the parameters $\delta$ that affect the expected value $E[Y \mid Y>0]$ conditional on $Y>0$, i.e. ,

$$
\begin{aligned}
& \quad D=1: E\left[Y \mid D=1, X_{2}\right]=E\left[Y \mid Y>0, X_{2}\right] \\
& =\left(X_{2}^{\prime} \delta+\varepsilon_{2} \mid Y>0, X_{2}\right)
\end{aligned}
$$

where $X_{2}$ includes the determinants of the dependent variable $Y, \varepsilon_{2}$ and is another error term. Generalised linear model with the assumption of gaussian or gamma distribution and/or id or log link, the coefficients are to be estimated. To select the model among these set of choices, Akaike Information Criterion (AIC) and Bayesian Information Criterion (BIC) are utilised (Table 1). It is evident from the table that Logit model for first part and GLM with gamma and log link for second part are more appropriate. The expenditure has been calculated in Indian Rupees(INR) by NSSO and therefore, the present analysis is done in the same currency. 
Table 1: Akaike Information Criterion (AIC) and Bayesian Information Criterion (BIC) for possible two-part models.

\begin{tabular}{|l|l|l|l|l|}
\hline $\begin{array}{l}\text { Sr. } \\
\text { No. }\end{array}$ & $\begin{array}{l}\text { First } \\
\text { Part }\end{array}$ & Second Part & AIC & BIC \\
\hline 1 & Probit & $\begin{array}{l}\text { GLM with Gaussian } \\
\text { and id Link }\end{array}$ & 320935.9 & 321390.9 \\
\hline 2 & Probit & $\begin{array}{l}\text { GLM with Gaussian } \\
\text { and log Link }\end{array}$ & 320481.8 & 320936.8 \\
\hline 3 & Probit & $\begin{array}{l}\text { GLM with Gamma } \\
\text { and id Link }\end{array}$ & 282971.9 & 283426.9 \\
\hline 4 & Probit & $\begin{array}{l}\text { GLM with Gamma } \\
\text { and log Link }\end{array}$ & 282714.7 & 283169.6 \\
\hline 5 & Logit & $\begin{array}{l}\text { GLM with Gaussian } \\
\text { and id Link }\end{array}$ & 320934.8 & 321389.8 \\
\hline 6 & Logit & $\begin{array}{l}\text { GLM with Gaussian } \\
\text { and log Link }\end{array}$ & 320480.7 & 320935.7 \\
\hline 7 & Logit & $\begin{array}{l}\text { GLM with Gamma } \\
\text { and id Link }\end{array}$ & 282970.9 & 283425.8 \\
\hline 8 & Logita & $\begin{array}{l}\text { GLM with Gamma } \\
\text { and log Linka }\end{array}$ & $282713.6 \mathrm{a}$ & $283168.6 \mathrm{a}$ \\
\hline
\end{tabular}

${ }^{a}$ preferred model.

\section{Result and Discussion}

For 14510 cases of childbirth, total health expenditure has been divided into medical and non-medical expenditure (Table 2). Medical expenditure includes doctor's fee, cost of medicines, money spent of diagnostic tests etc, non-medical expenditure include money spent on transportation, accommodation etc. On average, medical, non-medical, and totalexpenditure on childbirth is INR.7758, INR. 1345, and INR. 9103 respectively, however median medical, non-medical, and total expenditure is INR. 2200,

Table 2: Expenditure incurred by inpatients for Childbirth in India (In Rupees): NSSO's $71^{\text {st }}$ round (January to June, 2014)

\begin{tabular}{|l|c|c|c|}
\hline & $\begin{array}{c}\text { Direct } \\
\text { Medical } \\
\text { expenditure }\end{array}$ & $\begin{array}{c}\text { Direct } \\
\text { Non-medical } \\
\text { expenditure }\end{array}$ & $\begin{array}{c}\text { Total direct } \\
\text { health } \\
\text { expenditure }\end{array}$ \\
\hline Number (N) & 14510 & 14510 & 14510 \\
\hline Mean & 7758 & 1345 & 9103 \\
\hline Median & 2200 & 850 & 3570 \\
\hline $\begin{array}{l}\text { Co-efficient of } \\
\text { Variation }\end{array}$ & 2.11 & 1.20 & 1.88 \\
\hline Skewness & 11 & 4 & 11 \\
\hline Minimum & 0 & 0 & 0 \\
\hline Maximum & 800000 & 40000 & 813000 \\
\hline
\end{tabular}

Source: Unit level data (NSSO, 2015)
INR. 850, and INR. 3570 resp. The standard deviation and co-efficient of variation reveals that there is high variation in the health expenditure. On the one hand, households are not spending any money for childbirth and on the other hand, households are spending around 0.8 million rupees. Apart from excessive heterogeneity, the data of healthcare expenditure for childbirth is also skewed. The high value of mean than median signify that the data is positively skewed. The researchers dealing with health expenditure data concur to the fact that this is common feature of health expenditure data (Jones, 2010).

The definition of the variable utilised in the analysis is given in the table 3. To study the factors impacting the expenditure on childbirth, the results of two-part models are presented in Table 4. As discussed in the methodology, in the first part of the model, the results of the logit model are presented. It indicates the determinants of expenditure on childbirth and in the second part results of generalised linear model with gamma distribution and log link are presented. It indicates the factors impacting the quantity/ level of expenditure on childbirth in India.

\subsection{Factors Influencing the Expenditure on Childbirth}

On the one hand, from the logit model, household size, per capita monthly expenditure, employment as causal labourer in agriculture, residence in northern part of India vis-à-vis north-central India, childbirth at public health facilities, and government insurance significantly reduces the probability of spending any money on childbirth. On the other hand, residence of women in north-eastern states vis-a-vis central zone of India, duration of stay at the hospital, ante-natal care, and surgery significantly increase the probability of expenditure on childbirth.

From the results of the two-part model, it is evident that household size, per capita expenditure, and women belonging to northern zone of India can impact the expenditure on childbirth in an interesting way. On the one hand, large household size, economically better off households, or women belonging to prosperous northern zone of India have low probability of spending money on Childbirth. On the other hand, for large households, economically betteroff households or women belonging to prosperous northern zone of India, the extent/level/quantity of expenditure on childbirth increases. This reveals that the better-off people of India also enjoy the benefits of free schemes for childbirth as compared to poor people. This finding is in accordance with the view prevalent in the other parts of developing world that the economically better-off segment of people is more likely to receive government benefits than the worse-off segment. The findings by(Singh \& Kumar, 2009), (Gupta \& 
Table 3: Definition of variables utilized in modelling of health expenditure on childbirth

\begin{tabular}{|c|c|}
\hline Variable & Definition \\
\hline HH size & Family Members of households \\
\hline PC expenditure & Per capita monthly expenditure incurred by households (In 1,000 Rupees) \\
\hline Causal labourer agriculture & Dummy $=1$ if the person belongs to household who are casual labourer in agriculture in rural area, 0 otherwise \\
\hline $\begin{array}{l}\text { Causal labourer non- } \\
\text { agriculture }\end{array}$ & $\begin{array}{l}\text { Dummy=1 if the person belongs to household who are casual labourer in non-agriculture in rural area, } 0 \\
\text { otherwise }\end{array}$ \\
\hline Causal labourer Urban & Dummy $=1$ if the person belongs to household who are casual labourer in urban area, 0 otherwise \\
\hline Religious minority & $\begin{array}{l}\text { Dummy=1 if the person belongs to minority religious group Muslim, Christianity, Jainism, Buddhism etc., } \\
0 \text { otherwise }\end{array}$ \\
\hline Caste & $\begin{array}{l}\text { Dummy }=1 \text { if the person belongs to Schedule caste, Schedule tribe or backward castes notified by Govt. of } \\
\text { India, } 0 \text { otherwise }\end{array}$ \\
\hline Rural & Dummy $=1$ if the person belongs to rural area, 0 otherwise \\
\hline Educated Head & Dummy=1 if the person belongs to household whose head is educated, 0 otherwise \\
\hline Age & Age of the person (In years) \\
\hline Educated & Dummy $=1$ if the person is educated, 0 otherwise \\
\hline North Eastern & Dummy $=1$ if the person belongs to North-Eastern zone of India, 0 otherwise \\
\hline Southern & Dummy $=1$ if the person belongs to Southern zone of India, 0 otherwise \\
\hline Western & Dummy $=1$ if the person belongs to Western zone of India, 0 otherwise \\
\hline Eastern & Dummy $=1$ if the person belongs to Eastern zone of India, 0 otherwise \\
\hline Northern & Dummy $=1$ if the person belongs to Northern zone of India, 0 otherwise \\
\hline Duration & Number of overnight stays in the hospital (In days) \\
\hline Special ward & Dummy $=1$ if the person was admitted in the special ward/room in hospital, 0 otherwise \\
\hline Surgery & Dummy=1 if the any surgery was performed during stay in the hospital, 0 otherwise \\
\hline Scan & Dummy=1 if the X-ray/ECG/EEG/any Scan was performed on the person, 0 otherwise \\
\hline Different State & Dummy $=1$ if the place of hospitalisation is different from home state of the person, 0 otherwise \\
\hline ANM & Dummy=1 if the healthcare was sought from HSC/ANM/ASHA/AWW, 0 otherwise \\
\hline PHC & Dummy=1 if the healthcare was sought from PHC/dispensary/CHC/mobile medical unit, 0 otherwise \\
\hline Public Hospital & Dummy=1 if the healthcare was sought from public hospital, 0 otherwise \\
\hline Healthcare before Inpatient & Dummy=1 if any healthcare was sought before hospitalization, 0 otherwise \\
\hline Package & Dummy $=1$ if the person availed care services in any package, 0 otherwise \\
\hline Insurance by Government & Dummy $=1$ if the person had insurance provided by Government or Government agencies, 0 otherwise \\
\hline Insurance by Employer & Dummy $=1$ if the person had insurance provided by Employer, 0 otherwise \\
\hline Own Insurance & Dummy $=1$ if the person had purchased any insurance themselves, 0 otherwise \\
\hline Reimbursement & Dummy= 1 if the person received any reimbursement from any source, 0 otherwise \\
\hline Dependent Variable & Total health expenditure in Rupees. \\
\hline
\end{tabular}

Source: Unit level data (NSSO, 2015)

Dasgupta, 2002), and (Mahal, Yazbeck, Peters, \& Ramana, 2001) on India also suggest the same thing. Moreover, with increase in members of household, the households can have more number of caregivers and also could draw more resourcesfor expenditure on childbirth and therefore large households can spend more. Large households can also have large social networks and this can aware the patients regarding various benefits of public and private policies and programs (Minh, Phuong, Saksena, James, \& Xu, 2013). Probably due to this, with increase in household size, the probability of any expenditure on childbirth declines. However, for households who spend money, with increase in number of members the quantity/level of expenditure increases. 
Table 4: Determinants of expenditure on hospitalisation due to childbirth: Two-part model

\begin{tabular}{|c|c|c|c|c|c|c|c|}
\hline \multirow{2}{*}{ Variable } & \multicolumn{3}{|c|}{ Logit Model } & \multicolumn{3}{|c|}{ GLM with Gamma distribution and log link } & \multirow{2}{*}{$\begin{array}{c}\text { Average } \\
\text { Marginal } \\
\text { Effects }\end{array}$} \\
\hline & Co-efficient & Standard Error & p-value & Co-efficient & Standard Error & p-value & \\
\hline HH size & -0.099 & $\mathbf{0 . 0 3 2}$ & 0.002 & 0.039 & 0.005 & $\mathbf{0 . 0 0 0}$ & 1149.54 \\
\hline PC expenditure & -0.220 & 0.072 & 0.002 & 0.132 & 0.014 & 0.000 & 5123.98 \\
\hline $\begin{array}{l}\text { Causal labourer } \\
\text { agriculture }\end{array}$ & -0.566 & 0.296 & 0.056 & -0.188 & 0.051 & 0.000 & -16206.27 \\
\hline $\begin{array}{l}\text { Causal labourer non- } \\
\text { agriculture }\end{array}$ & 0.541 & 0.414 & 0.192 & -0.096 & 0.049 & 0.053 & -146.00 \\
\hline Causal labourer Urban & -0.441 & 0.331 & 0.183 & -0.151 & 0.054 & 0.006 & -12851.05 \\
\hline Religious minority & -0.261 & 0.225 & 0.247 & -0.069 & 0.031 & 0.025 & -6494.44 \\
\hline Caste & 0.061 & 0.229 & 0.789 & -0.132 & 0.029 & 0.000 & -6733.82 \\
\hline Rural & 0.256 & 0.239 & 0.284 & 0.019 & 0.031 & 0.533 & 3647.48 \\
\hline Educated Head & -0.100 & 0.207 & 0.630 & 0.095 & 0.031 & 0.002 & 4279.15 \\
\hline Age & 0.023 & 0.011 & 0.034 & 0.005 & 0.001 & $\mathbf{0 . 0 0 0}$ & 531.74 \\
\hline Educated & 0.318 & 0.195 & 0.103 & -0.136 & 0.028 & 0.000 & -4333.68 \\
\hline North Eastern & 1.501 & 0.512 & 0.003 & 0.493 & 0.048 & 0.000 & 42606.16 \\
\hline Southern & 0.185 & 0.326 & 0.569 & 0.305 & 0.041 & 0.000 & 18864.39 \\
\hline Western & -0.491 & 0.318 & 0.122 & 0.142 & 0.045 & 0.001 & 2942.19 \\
\hline Eastern & -0.011 & 0.291 & 0.969 & 0.277 & 0.042 & 0.000 & 15270.66 \\
\hline Northern & -0.488 & 0.281 & 0.083 & 0.119 & 0.046 & 0.010 & 1692.00 \\
\hline Duration & 0.040 & 0.011 & 0.000 & 0.065 & 0.005 & 0.000 & 3206.07 \\
\hline Special ward & 0.459 & 0.791 & 0.562 & 0.204 & 0.044 & 0.000 & 15965.01 \\
\hline Surgery & 0.649 & 0.273 & 0.017 & 0.363 & 0.031 & 0.000 & 26737.40 \\
\hline Scan & 0.271 & 0.199 & 0.174 & 0.198 & $\mathbf{0 . 0 2 7}$ & 0.000 & 13755.17 \\
\hline Different State & 0.343 & 0.723 & 0.635 & 0.424 & 0.078 & 0.000 & 27045.07 \\
\hline ANM & -4.006 & 0.627 & 0.000 & -1.037 & 0.099 & 0.000 & -98203.08 \\
\hline PHC & -3.512 & 0.554 & 0.000 & -1.376 & 0.051 & 0.000 & -112065.90 \\
\hline Public Hospital & -2.641 & 0.523 & 0.000 & -1.124 & 0.033 & 0.000 & -89244.01 \\
\hline $\begin{array}{l}\text { Healthcare before } \\
\text { Inpatient }\end{array}$ & 0.635 & 0.224 & 0.005 & 0.055 & 0.039 & 0.155 & 9492.80 \\
\hline Package & --N.A.-- & --N.A.-- & --N.A.-- & 0.516 & 0.039 & 0.000 & 28732.89 \\
\hline $\begin{array}{l}\text { Insurance by } \\
\text { Government }\end{array}$ & -1.047 & 0.224 & 0.000 & -0.130 & 0.042 & 0.002 & -17812.36 \\
\hline Insurance by Employer & -0.041 & 1.024 & 0.968 & -0.007 & 0.107 & 0.949 & -796.45 \\
\hline Own Insurance & -0.439 & 1.079 & 0.684 & -0.122 & 0.116 & 0.293 & -11251.26 \\
\hline Reimbursement & --N.A.-- & --N.A.-- & --N.A.-- & $\mathbf{0 . 2 7 7}$ & 0.086 & 0.001 & 15431.99 \\
\hline Constant & 6.865 & 0.758 & 0.000 & 8.179 & 0.085 & 0.000 & \\
\hline Number of Obs. & \multicolumn{3}{|c|}{14510} & \multicolumn{3}{|c|}{14385} & \\
\hline Log-likelihood & \multicolumn{3}{|c|}{-615.37} & \multicolumn{3}{|c|}{-140681.44} & \\
\hline Log-pseudolikelihood & \multicolumn{6}{|c|}{-141296.81} & \\
\hline
\end{tabular}

Note: N.A. signify not applicable. Package and Reimbursement were dropped in the first model.

Source: Unit level data NSSO (2015) 


\subsection{Factors influencing the quantity of expenditure on childbirth}

Apart from household size and economic status, for households engaged as causal labour in rural agriculture sector, in rural non-agriculture sector, and in urban areas, the spending on childbirth is less as these households do not have a permanent source of income and usually have meagre resources. The women belonging to religious minorities like Muslims, Christians, Buddhists, and Sikh are spending less on childbirth. The same is true for women belonging to lower caste categories (Notified as Schedule Caste(SC), Schedule Tribe (ST) or backward castes(BC) by Govt. of India). As per estimates of average marginal effects, these women spend approximately INR. 6500 less as compared to other women. This signify that there are stark differences on account of spending on childbirth between the religious minorities and lower caste groups vis-à-vis majority population and upper caste groups. Households having educated head are usually more aware and informed and have more resources. These households are spending more on childbirth (around INR. 4280) as compared to households with uneducated head. With increase in age, the complexity to give birth can also increase (Campbell, 2010) (Soonawala, 2010). It can increase the expenditure on ante-natal, natal, and postnatal care. With increase in age of women by one year, the expenditure on childbirth increases by INR. 532 .

Education status of the women can also impact the expenditure on childbirth. On the one hand, educated women generally can have greater access to resources as compared to uneducated women. On the other hand, educated women are more likely to adopt simple and lowcost hygienic practises. Moreover, educated person is more likely to be better informed about the current policies and programs of the government which can significantly decrease the risk of high costs and high maternal mortality. Educated women can also take informed decision regarding the choice of ante-natal, natal, and post-natal care. (Ashraf, Field \& Lee, 2014). Probably due to these reasons, educated women in India are spending INR. 4334 less as compared to uneducated women.

Furthermore, entire India is divided into six geographical zones namely: Eastern, North-Central, NorthEastern, Northern, Southern, Western. Each zone consists of 5-7 states of India. Although, there is great heterogeneity within Indian states, to compare and contrast the behaviour of people residing into different zones of India, these zone as independent variables are utilised and the north-central zone is utilised as reference/base category and rest of the five zones are target categories. Women belonging to northeastern zone, southern zone, western zone, eastern zone, and northern zone are spending more than women belonging to central zone. A variety of localised factors like accessibility of infrastructure, number of doctors etc. must be playing critical role in impacting the expenditure on childbirth. As compared to central zone, northern zone and western zone are spending slightly higher (Approximately INR.15003000). In the case of southern and eastern zone the expenditure on childbirth is approximately 15-19000 INR. higher than central zone. However, in case of north-eastern zone the expenditure on childbirth is higher as compared to other zones. The states in north-eastern zone are Assam, Arunachal Pradesh, Manipur, Meghalaya, Mizoram, Nagaland, and Tripura. Government of India in the annual report 2014-15 of Ministry of health and family welfare identified that in these states there is problem of access to health facilities, shortage of trained staff, quality of health services, high morbidity and mortality due to malaria etc. Moreover, in these states due to bad infrastructure and other socio-cultural issues, it is no wonder that women belonging to these regions end-up spending much more than rest of parts of India (Prakash \& Saxena, 2016).

The stay at the hospital during childbirth also positively impacts the expenditure. Women opting for special room or ward also spend significantly more vis-a-vis others. Women giving birth with surgery/caesarean -section also spend more than others. In the last decade or so, the proportion of births delivered by caesarean section has also gone up. The findings of National Family Health Survey-4 in India also suggest that $\mathrm{C}$-section is common in private health facilities, in urban areas, among the more educated women, and among the wealthier people (IIPS \& ICF, 2017). Women having any CT scan or ultrasound or x-ray or any other type of diagnostic scans during the hospitalisation spend approximately INR. 13755 rupees more than as compared to women undergoing none of these scans. For women giving birth to a child away from its home states, are likely to spend INR. 27045 more as compared to women who give birth in their home states. Hospitalisation away from home state/home district may increase the direct nonmedical expenditure like bedding, lodging, transport, and accommodation charges.

The government of India through its various initiatives and programmes have trained workforce at rural or semi-urban or urban health facilities of India like Health Sub-Centre (HSC), Angan-wadi worker(AWW), Auxiliary Nurse Midwives (ANM), Accredited Social Health Activist(ASHA), Primary Health Centre(PHC), Mobile Medical Unit (MMU), and Community Health Centre (CHC). This health infrastructure has been created by the government over the years to provide basic public health facilities. Around 2 percent of the sample utilises HSC/AWW/ANM/ASHA health facilities for childbirth. 10 percent of the sampled cases utilises $\mathrm{PHC} /$ 
public dispensary/ MMU/CHC for childbirth. Around 50 percent of the inpatients utilise public hospital for childbirth. This implies that for childbirth public health facilities are slightly preferred over private health facilities as approximately 62 percent of the inpatients availed public health facilities(NSSO, 2015). The findings in the table 4 reveal that the women giving birth to a child in these public health facilities are spending less as compared to private hospitals. The findings suggest that public sector hospitals are fairly economically for childbirth. However, there are concerns over the quality of public health facilities for maternal health and childbirth. Despite the efforts and improvements in quality of maternal health services in the recent past, a lot has to be done to bring the quality of health services in India at par with advanced and emerging economies of the world (Nair \& Panda, 2011).

Moreover, the private sector healthcare facilities have been diversified over the years. The recent decades have witnessed transformation of private health facilities from informal to formal and gradually to corporatisation. In the present period, government'sliberalised policy for foreign direct investment in health sector, coupled with rising paying capacity, people's awareness, and changing nature of diseases have also strengthenedthe private health providers (Kumar, 2015). Despite the low-cost health facilities of public health sector and rising suspicion of the people that private health providers perform unnecessary tests and surgeries and charge exorbitantly high; households also prefer private health facilities (Kesterton, Cleland, Sloggett, \& Ronsmans, 2010). Many of the private health providers offer packages for childbirth in which the charges like medicine, diagnostics tests, bedding, and lodging etc. are all inclusive. Households opting for these packages spend significantly more as compared to women not opting any package.

The safety nets like insurance (public or private) can assist in mitigating the adverse impacts of healthcare costs on the household (Kumar S. , 2015). Women covered by various insurance schemes or policies of government are spending around INR. 17812 less as compared to other women. However, for women getting any reimbursements from any source (public and private) are likely to spend more (around INR. 15432) as compared to other women. Interestingly, upon further delving into the sampled data, it was found that only around 3 percent of the women received any reimbursement for the expenditure done. Findings of National Family Health Survey (NFHS)-4 also suggest that medical reimbursement is not the preferred mode for households (IIPS \& ICF, 2017). Majority (more than 60 percent) of women receiving any reimbursement from any source sought treatment from private health facilities. However, among the women covered under any government insurance scheme, majority of them (more than 60 percent) sought treatment from public health facilities. Moreover, in case of reimbursement the households initially have to spend money from their own pocket and many-a-times there is also limit to reimbursed amount. Possibly due to these reasons, and the limitations of medical reimbursement, the spending on childbirth is higher for women receiving reimbursement (Columbia University, n.d.).

\section{Conclusion}

It is evident from the present study that Government of India's various health facilities and its programmes are assisting in decreasing the economic burden of institutional deliveries for women. However, to further increase the utilisation of public health facilities there is need to strengthen the current infrastructure and policies and there is also dire need to improve the quality of public health facilities. Large investments in healthcare are also required especially in the backward parts of country like north-east zone as health expenditure on institutional deliveries is higher for this part of the country. To reduce the economic burden of institutional deliveries for households, the health insurance coverage need to be improved through various initiatives like making premium affordable, increasing awareness, and improving management and organisation of insurance scheme etc.

\section{References}

Ashraf, N., Field, E., \& Lee, J. (2014, July). Household Bargaining and Excess Fertility: An Experimental Study in Zambia. American Economic Review, 104(7), 2210-2237. https://doi.org/10.1257/aer.104.7.2210

Alfo, M., \& Maruotti, A. (2010). Two-part regression models for longitudinal zero-inflated count data. The Canadian Journal of Statistics / La Revue Canadienne de Statistique, 38(2), 197-216. Retrieved from https://doi.org/10.1002/cjs.10056

Campbell, D. (2010, December 31). https://www.theguardian. com/society/2010/dec/31/pregnancy-mothers-fertilitychildren. Retrieved 5 27, 2018, from www.theguardian.com/: https://www.theguardian.com/society/2010/dec/31/ pregnancy-mothers-fertility-children

CBHI, C. B. (2016). National Health Profile, 2015. New Delhi: Central Bureau of Health Intelligence. Retrieved 5 27, 2018, from

http://www.indiaenvironmentportal.org.in/files/file/ NHP-2015.pdf

Columbia University. (n.d.). Healthcare in India. Healthcare in India. United Kingdom: Columbia University. Retrieved 527, 2018, from http://assets.ce.columbia.edu/pdf/actu/actu-india.pdf 
Dow, W. H., \& Norton, E. C. (2003). Choosing Between and Interpreting the Heckit and Two-Part Models for Corner Solutions. Health Services and Outcomes Research Methodology, 4(1), 5-18. https://doi.org/10.1023/A:1025827426320

Farewell, V. T., Long, D. L., Tom, B. D. M., Yiu, S., \& Su, L. (2017). Two-Part and Related Regression Models for Longitudinal Data. Annual Review of Statistics and Its Application, 4(1), 283-315. https://doi.org/10.1146/annurev-statistics-060116-054131

Gregori, D., Petrinco, M., Desideri, A., Merletti, F., \& Pagano, E. (2011, April 19). Regression models for analyzing costs and their determinants in health care: an introductory review. International Journal for Quality in Health Care, 23(3), 331-341. https://doi.org/10.1093/intqhc/mzr010

Gupta, I., \& Dasgupta, P. (2002). Health-seeking behaviour in urban Delhi: an exploratory study. World Health and Population, 3(2), 1. https://doi.org/10.12927/whp..17580

IIPS, I. I., \& ICF. (2017). National Family Health Survey (NFHS4), 2015-16: India. Mumbai: International Institute for Population Sciences (IIPS). Retrieved 5 25, 2018, from http://rchiips.org/NFHS/NFHS-4Reports/India.pdf

Jones, A. M. (2010, January). Models For Health Care. HEDG Working Paper, 10/01. Retrieved 5 28, 2018, from https:/www.york.ac.uk/media/economics/documents/ herc/wp/10_01.pdf

Kesterton, A. J., Cleland, J., Sloggett, A., \& Ronsmans, C. (2010). Institutional delivery in rural India: the relative importance of accessibility and economic status. $B M C$ Preganancy Childbirth, 10, 30.

https://doi.org/10.1186/1471-2393-10-30

Kumar, S. (2015). Financial Consequences of Illness: Evidence from slums of India. New Delhi: Cambridge University Press India Pvt Ltd (CUPIPL).

Kumar, S. (2015). Private Sector in Healthcare Delivery Market in India: Structure, Growth and Implications. New Delhi: Institute for Studies in Industrial Development (ISID). Retrieved 05 26, 2018, from http://isid.org.in/pdf/WP185.pdf

Leung, S. F., \& Yu, S. (1996). On the choice between sample selection and two-part models. Journal of Econometrics, 72(1-2), 197-229. https://doi.org/10.1016/0304-4076(94)01720-4

Madden, D. (2006). Sample Selection Versus Two-Part Models Revisited: The Case of Female Smoking and Drinking. Health Econometrics and Data Group (HEDG)-Working Paper, 6/12, 1. Retrieved 5 27, 2018, from https://www.york.ac.uk/media/economics/documents/ herc/wp/06_12.pdf

Mahal, A., Yazbeck , A., Peters, D., \& Ramana, G. (2001, August). THE POOR AND HEALTH SERVICE USE
IN INDIA. Health Nutrition and Population (HNP) Discussion Paper, 1. Retrieved 5 25, 2018, from http://siteresources.worldbank.org/ HEALTHNUTRITIONANDPOPULATION/ Resources/281627-1095698140167/Mahal-

ThePoorAnd-whole.pdf

Minh, H. V., Phuong, N. T., Saksena, P., James, C. D., \& $\mathrm{Xu}$, K. (2013). Financial burden of household out-of pocket health expenditure in Viet Nam: Findings from the National Living Standard Survey 2002-2010. Social Science and Medicine, 96, 258-263.

https://doi.org/10.1016/j.socscimed.2012.11.028

Nair, H., \& Panda, R. (2011). Quality of maternal healthcare in India: Has the National Rural Health Mission made a difference? Journal of Global Health, 1(1), 79-86. Retrieved 05 26, 2018, from https:/www.ncbi.nlm.nih.gov/pmc/articles/PMC3484741/

Neelon, B., \& O'Malley, A. J. (2019). Two-Part Models for ZeroModified Count and Semicontinuous Data (pp. 695-716). https://doi.org/10.1007/978-1-4939-8715-3_39

NITI-Ayog. (2017, 121$)$. Maternal Mortality Ratio. Retrieved 5 27, 2018, from niti.gov.in: http://niti.gov.in/content/ maternal-mortality-ratio-mmr-100000-live-births\#

NSSO, N. S. (2015, July 28). Social Consumption in India: Health, NSS 71st Round. Social Consumption in India: Health, NSS 71st Round. New Delhi, New Delhi, India: National Sample Survey Office - Ministry of Statistcs and Programme Implementation(MOSPI), Government of India (GOI).

Prakash, A., \& Saxena, A. (2016). Health in north-east region of India - The new focus of attention. Indian Journal of Medical Specialities, 7, 93-94.

https://doi.org/10.1016/j.injms.2016.09.013

Russell, S. (2004). The Economic Burden of Illness for Households in Developing Countries: A Review of Studies Focusing on Malaria, Tuberculosis, and Human Immunodeficiency Virus/Acquired Immunodeficiency Syndrome. American Journal of Tropical Medicine and Hygiene, 71(2 (Supplementary)), 147-155. Retrieved 5 27, 2018, from https://doi.org/10.4269/ajtmh.2004.71.147

Singh, S., \& Kumar, S. (2009). Determinants of Health Seeking Behaviour of Households in Punjab. Research Journal of Social Sciences, 17(1), 33-49.

Soonawala, R. P. (2010, December 16). https://www. indiatoday.in/lifestyle/health/story/pregnancy-after-30tough-or-easy-87196-2010-12-16. Retrieved 5 27, 2018, from www.indiatoday.in:

https://www.indiatoday.in/lifestyle/health/story/ pregnancy-after-30-tough-or-easy-87196-2010-12-16 
Tripathy, J. P., Shewade, H. D., Mishra, S., Kumar, A., \& Harries, A. (2017). Cost of hospitalization for childbirth in India: how equitable it is in the post NRHM era? BMC research Notes, 10, 409.

https://doi.org/10.1186/s13104-017-2729-z 